\title{
STUDIES IN EDEMA. IV. WATER RETENTION AND THE ANTI- DIURETIC HORMONE IN HEPATIC AND CARDIAC DISEASE ${ }^{1,2}$
}

\author{
By ABRAHAM G. WHITE,, 4 GEORGE RUBIN, AND LOUIS LEITER
}

(From the Medical Division, Montefiore Hospital, New York City, N. Y.)

(Submitted for publication February 23, 1953; accepted June 3, 1953)

\section{INTRODUCTION}

Current opinion concerning the impaired output of water in patients suffering from cirrhosis of the liver $(1,2)$ or from congestive heart failure (3) emphasizes primarily the impaired excretion of sodium with consequent retention of water, and only secondarily tends to implicate the neurohypophysial antidiuretic hormone as a responsible agent $(4,5)$. The present studies and discussion are meant to explore more fully the physiology of this hormone in these diseases.

The relationship of the antidiuretic hormone to the abnormal retention of water in edematous states has been studied in several ways. Thus, following oral hydration with water, impaired water diuresis ${ }^{5}$ has been demonstrated in patients with cirrhosis of the liver $(4,6,7)$, and a water tolerance test based on this phenomenon has been employed for some years. A subnormal urinary excretion of water following intravenous hydration with 5 per cent glucose in water in some patients with cirrhosis has also been reported (4). Similarly, delayed water diuresis following the

1 Presented in abstract form in the program of the Forty-Fourth Annual Meeting of the American Society for Clinical Investigation at Atlantic City, New Jersey on May 5, 1952.

2 This study has been supported by a grant from the American Heart Association.

8 Part of this work was done during the tenure of a Research Fellowship of the American Heart Association.

4 Present address: The Mount Sinai Hospital, New York City.

5 Water diuresis may be characterized with respect to the (a) time required to attain peak diuresis; (b) level of peak diuresis reached; and (c) proportion of an administered water load excreted during a test period. By definition, then, the attainment of peak diuresis may be "delayed," the level of this peak may be "reduced," and if the volume of water excreted during the test period is subnormal, the water diuresis may be described as "impaired." oral ingestion of water by patients suffering from congestive heart failure has been reported (8).

In order to establish the possible retention of water independent of that of sodium in hepatic and cardiac disease, investigators have sought for, and reported, increased amounts of an antidiuretic substance (ADS) in the blood (9) and urine of patients with cirrhosis of the liver $(10,11,12)$ and in the urine of those suffering from congestive heart failure (13). Such increases in circulating and urinary ADS might be explained on the basis of overproduction of antidiuretic hormone, decreased "inactivation," ${ }^{6}$ or a combination of both processes.

Small doses of Pitressin have been administered intravenously to patients with hepatic cirrhosis in order to study the rate of inactivation, which proved to be normal in these subjects $(14,15)$. To the extent that the inactivating mechanisms for endogenous antidiuretic hormone and Pitressin are similar, a decreased rate of inactivation of antidiuretic hormone seems to be excluded. Evidence suggesting that the inactivating mechanisms for endogenous antidiuretic hormone and Pitressin are indeed similar in patients with hepatic cirrhosis has been recently provided by Bernstein and co-workers (16). These investigators reported essentially similar antidiuretic responses of cirrhotic patients and normal subjects to Pitressin and to intravenous nicotine salicylate, which discharged endogenous $\mathrm{ADH}$. Overproduction of this hormone, therefore, appears to be a more likely explanation for the reported increases of ADS in the blood and urine in cirrhosis (14), if ADS is indeed derived from or represents the neurohypophysial antidiuretic hormone. This will be discussed later in more detail.

B "Inactivation," as used in this text, applies to the disappearance of antidiuretic hormone from the circulating blood stream as a result of destruction, excretion, or some combination of these processes. 
Eisenmenger (2) has summarized some of the abnormalities of water metabolism in the patient with cirrhosis and ascites and their possible relationship to increased production of the antidiuretic hormone. Following the ingestion of sodium by the cirrhotic, the deficient excretion of this ion may result in such prolonged relative elevation of the serum sodium as to stimulate the secretion of $\mathrm{ADH}$. Hyponatremia may then reflect the retention of water out of proportion to sodium, due to this increased production of $\mathrm{ADH}$. Another possible cause of overproduction of $\mathrm{ADH}$ in the presence of a dilute extracellular fluid may be the stimulation of antidiuretic activity by a "volume receptor" in response to a decreased volume of cerebral blood and extracellular fluid. In support of such a hypothetical mechanism Eisenmenger adduces the work of Lewis, Buie, Sevier and Harrison (17), Leaf and Mamby (18), and Strauss, Davis, Rosenbaum, and Rossmeisl (19).

On the other hand, a report of prolonged antidiuresis following the intravenous administration of Pitressin to three patients in congestive heart failure (20) suggests a decreased rate of "inactivation" of Pitressin, and/or an increased sensitivity of the end-organ, the renal distal tubule.

Increased neurohypophysial antidiuretic activity resulting in water retention has also been suggested by the occurrence of hyponatremia in some patients with congestive heart failure (21-24). Stead (25) has discussed the objections to such a concept.

The specific aims of the present experiments have been to: (1) study water diuresis following intravenous hydration with 5 per cent glucose in water in patients with congestive heart failure; (2) observe the effects of Pitressin administered intravenously during the course of continuous intravenous hydration; and (3) compare the responses of these cardiac patients with those demonstrated previously by patients with cirrhosis of the liver, and by control subjects.

\section{EXPERIMENTAL}

Water diuresis following intravenous hydration with 5 per cent glucose in water was studied in 10 patients suffering from congestive heart failure. In six of these the effect of single intravenous doses of Pitressin ( 0.57 $\mathrm{mU}$ per $\mathrm{Kg}$.), administered during continued intravenous hydration, was also determined. Similar studies were performed on a patient with cirrhosis of the liver associated with ascites and edema (R. A.), in addition to those on hepatic patients reported previously (14). Table I presents a brief resume of the clinical features of these experimental patients. The ten cardiacs and J. C., a cirrhotic, were on a low-salt regimen $(500 \mathrm{mg}$. sodium per day); all other experimental subjects were on a regular intake of salt.

Each subject was in a fasting state for 15 hours. Prior to the beginning of the experiment, one glass of water was taken orally every half hour for two hours. An intravenous infusion of 5 per cent glucose in water (average flow of $10 \mathrm{cc}$. per minute) was then started and continued throughout the entire experiment. When the rate of urine flow reached and maintained a plateau for three collection periods (each approximately fifteen minutes long), 0.57 $\mathrm{mU}$ per $\mathrm{Kg}$. of Pitressin was injected rapidly into the infusion tubing near the needle.

The urinary bladder was washed out with distilled water and air at the end of each collection period (about fifteen minutes in length) through an indwelling six-holed catheter.

Blood specimens were obtained at the beginning of an experiment, at the height of the diuresis, at the height of antidiuresis, and at the end of the procedure.

The calculations and definitions employed in the present paper are the same as those used previously (14). The "per cent inhibition" =

\section{Expected diuresis minus observed diuresis $\times 100$ Expected diuresis}

The "expected diuresis" is the urine flow that would have been obtained if the initial rate, observed just before the Pitressin was injected, had been maintained throughout the period of Pitressin effect.

\section{METHODS}

Hematocrit determinations on heparinized blood were performed by centrifuging in Wintrobe tubes at $2,500 \mathrm{rpm}$. for 30 minutes. Serum and urinary creatinine chromogen concentrations were measured by Peters' modification of the Folin method (26); urinary sodium and potassium, and serum potassium and sodium were measured with an internal standard Perkin 52A flame photometer; serum sodium, as indicated, was measured by the Butler-Tuthill gravimetric method (27); chloride was determined by the Van Slyke-Hiller modification of Sendroy's iodometric method (28); and urinary glucose measured by the method of Benedict (29). Standard methods of statistical analysis were employed (30).

\section{RESULTS}

\section{A. Endogenous creatinine chromogen clearance}

The endogenous creatinine chromogen clearance averaged $67 \pm 21 \mathrm{cc}$. per min. in the cardiac patients; $85 \pm 9 \mathrm{cc}$. per min. in those with hepatic disease; and $80 \pm 25 \mathrm{cc}$. per min. for the controls (mean of $99.7 \mathrm{cc}$. for the non-arthritic controls, 
TABLE I

The effect of intravenous Pitressin on the renal excretion of water in congestive heart failure and in liver cirrhosis*

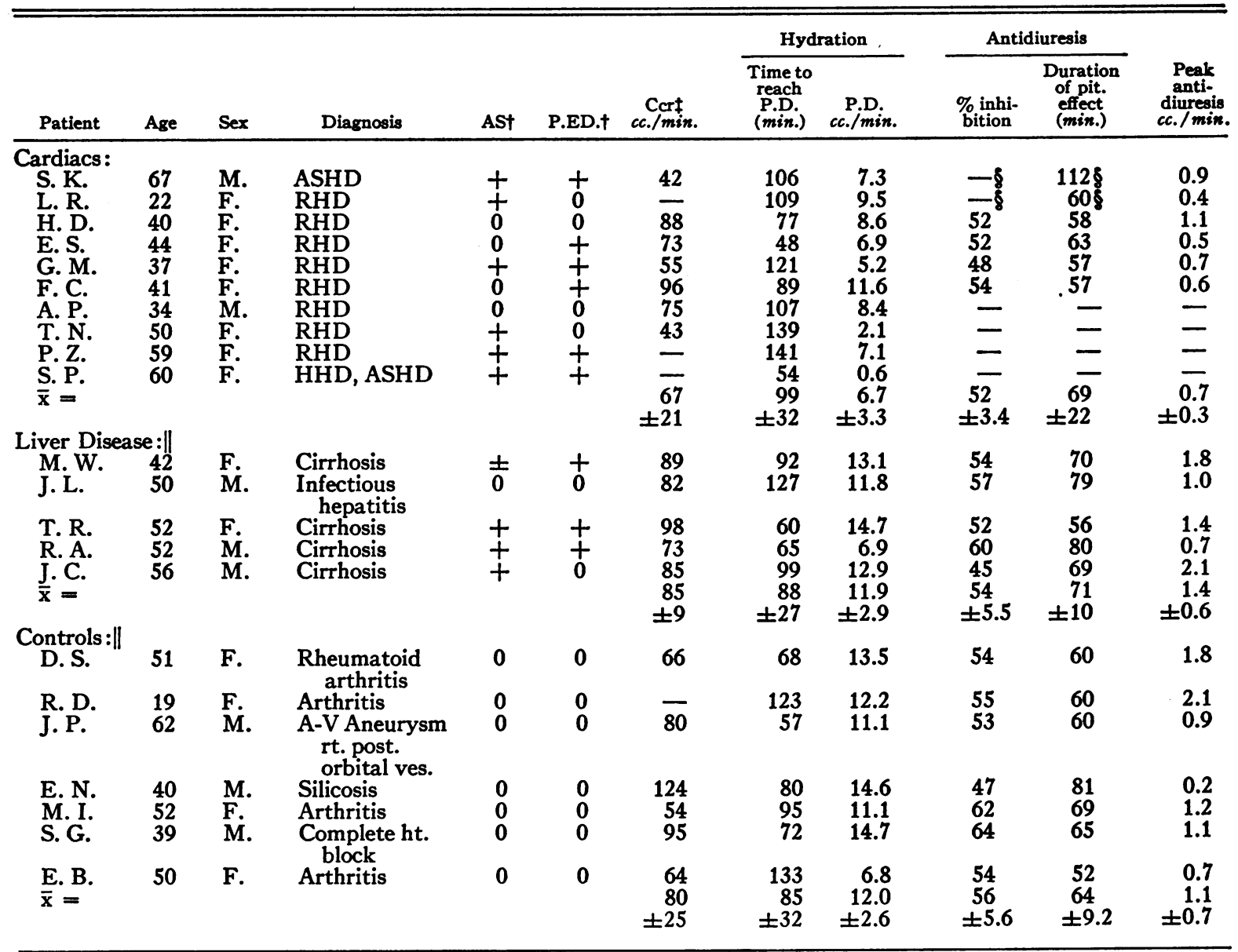

* The numbers in parentheses after the initials of the following cardiac subjects indicate the days preceding the experimental run on which a mercurial diuretic was administered; a number followed by an asterisk denotes the length of the hospital stay preceding the investigation, and represents a known minimum period during which no mercurials were administered: S. K. $\left(31^{*}\right)$; L. R. $\left(3^{*}\right)$; H. D. $(28,17,15,8)$; E. S. $\left(3^{*}\right)$; G. M. $\left(8^{*}\right)$; F. C. $(12,3)$; A. P. $\left(10^{*}\right)$; T. N. $(30,28,26,12)$; P. Z. $\left(10^{*}\right)$; and S. P. $(19,14,8)$.

The absence or presence of ascites and peripheral edema is denoted by 0 or + , respectively.

† AS-Ascites; P.ED.-Peripheral Edema.

$\mp$ Ccr-Endogenous Creatinine Clearance.

Urine flow did not return to pre-Pitressin level during experimental period.

Abbreviations: P.D.-Peak Diuresis; ASHD-Arteriosclerotic heart disease; RHD-Rheumatic heart disease; HHD-Hypertensive heart disease.

II Data on these patients (except for R. A.) have been presented previously.

Note: All ten cardiac patients were in congestive heart failure.

and $61 \mathrm{cc}$. per min. for the patients with arthritis) (Table I).

\section{B. Excretion of water}

Following the onset of the intravenous infusion of 5 per cent glucose in water, the time required for attainment of peak diuresis did not differ significantly, statistically, in any of the three groups of subjects: $99 \pm 32,88 \pm 27$, and $85 \pm 32 \mathrm{~min}-$ utes for the cardiac, hepatic, and control subjects, respectively (Table I, Figure 1 ); $P=0.36$ for cardiacs vs. controls, and 0.53 for cardiacs vs. cirrhotics. On the other hand, the level of peak diuresis was significantly lower in the patients suffering from congestive heart failure ( $6.7 \pm 3.3$ cc. per min.) than in the controls $(12.0 \pm 2.6 \mathrm{cc}$. per min. $)(P=0.003)$ or in the hepatic patients $(11.9 \pm 2.9$ cc. per min.) $(P=0.009)$ (Table $I$, 


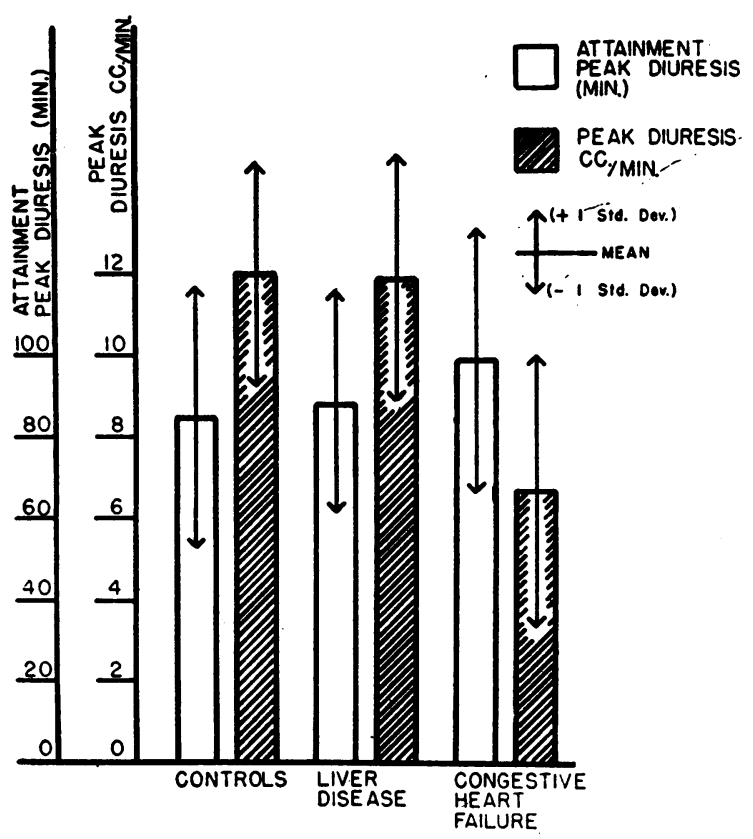

Fig. 1. The Time Required to Attain Peak Diuresis Following the Onset of Intravenous Hydration with 5 Per Cent Glucose in Water (10 cc. per min.) and the Level of Peak Diuresis Attained

Figure 1). Four of the cardiacs were not given Pitressin; in two of these (T. N. and S. P.) the urine flow during the hydration period did not reach rates deemed high enough, while restiveness in the other two (A. P. and P. Z.) precluded complete study.

Of the six cardiac patients in whom the effects of intravenous Pitressin ( $0.57 \mathrm{mU}$ per $\mathrm{Kg}$.) were studied, five demonstrated responses which were similar to those reported for controls and for hepatic patients. The "per cent inhibition" and duration of Pitressin effect could not be calculated for $L$. R. because the experiment was not run long enough to permit the urine flow to return to prePitressin levels. Thus, for the four cardiac patients, H. D., E. S., G. M., and F. C., the duration of Pitressin antidiuresis averaged $58.6 \pm 3.4 \mathrm{~min}$. ( $P=0.20$ for cardiacs $v s$. controls, and 0.12 for cardiac vs. hepatic patients). The "per cent inhibition" of diuresis in the patients with congestive heart failure averaged $51.7 \pm 3.4$ per cent $(P=$ 0.16 for cardiacs $v s$. controls, and 0.55 for cardiac vs. hepatic patients) (Figure 2). The other cardiac patient, S. K., demonstrated an enhanced Pitressin antidiuresis (Figure 3 ).

\section{Serum electrolytes}

Table II presents the effect of Pitressin on the serum electrolytes. Pitressin had no statistically significant effect on the serum concentrations of sodium, chloride or potassium in the cardiac patients (except G. M.).

Although the initial concentrations of sodium and chloride in the serum tended to be lower in the cardiac patients than in the other groups, the only statistically significant difference was that observed in the chlorides.

\section{Urinary electrolytes}

The renal excretion ( $\mathrm{mEq}$. per min.) of sodium and chloride during the hydration period $(\mathrm{H})$ as well as during antidiuresis was significantly lower in the cardiac than in the controls (for chloride, $P=0.006$ and for sodium, $P=0.004$ ). If one of the cirrhotics, M. W., is excluded, there is no statistically significant difference in the urinary excretion of sodium and chloride between the cardiac and hepatic patients. The excretion of potassium in the urine (mEq. per min.) during the hydration period was the same for the three groups of experimental subjects.

Table III and Figure 4 demonstrate that Pitressin had no statistically significant effect on the minute output of urinary sodium, chloride or potassium, either in the cardiac patients or in the other two groups.

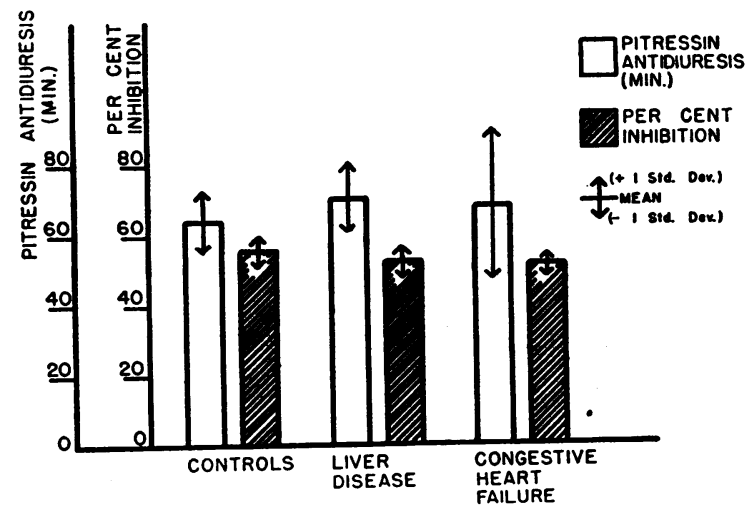

Fig. 2. The Duration of Pitressin Antidiuresis AND THE "Per Cent In hibition of DiUResis" Following THE INTRAVENOUS ADMinistration OF 0.57 MU PER KG. Pitressin to Continuously-Hydrated (Intravenous 5 Per Cent Glucose in Water) Subjects 


\section{DISCUSSION}

\section{A. Endogenous Creatinine Chromogen Clearance}

The low clearance values in the arthritic controls resulted from a diminished urinary excretion ( $\mathrm{mg}$. per min.), while the plasma concentrations were normal. This may be related to the abnormal glycine metabolism reported in rheumatoid arthritis (31), resulting possibly in a diminished synthesis of creatinine and creatine. Another possibility is that there may have been an increased creatinuria (as a result of muscular atrophy) with concomitantly diminished creatininuria.

\section{B. Excretion of Water}

\section{Time required for attainment of peak diuresis.}

Burn and Grewal (32) believe that the time required for the attainment of peak diuresis may be a measure of the $\mathrm{ADH}$ present (in the kidney and circulating in the blood) when the water was ingested. If this is correct, then the demonstration (that the time required for maximum diuresis in the patients with heart disease was not significantly different, statistically, from that observed in liver disease or in control subjects) would tend to exclude hypersecretion of ADH in our patients suffering from either of these diseases.

It is difficult to reconcile such apparent lack of hypersecretion and the absence of deficient inactivation of the hormone with the reported increases of an antidiuretic substance (ADS) in the urine of such patients as well as in the serum of cirrhotic patients, unless one were to assume that

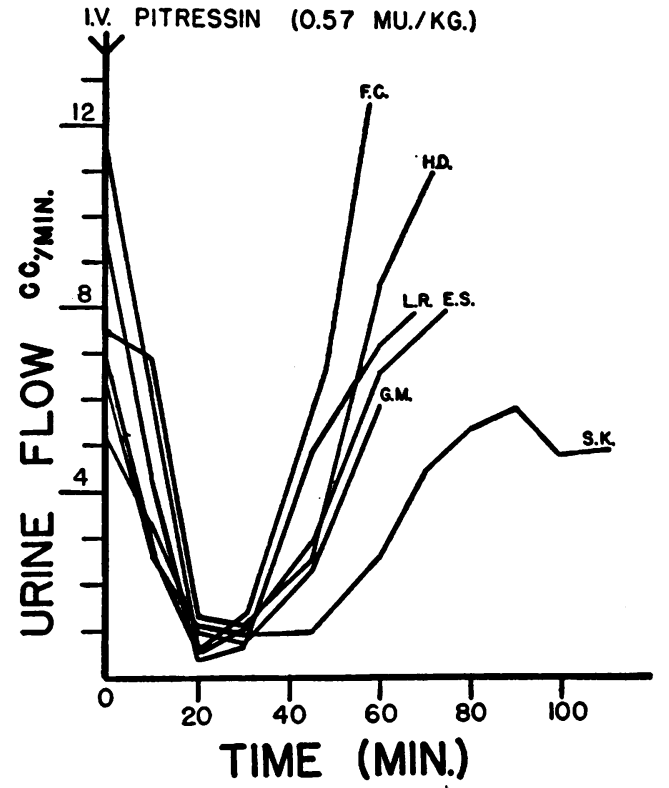

Fig. 3. The Efrect of Intravenous Pitressin (0.57 MU Per KG.) on the Urine Flow in ContinuouslyHydrated (Intratenous 5 Per Cent Glucose in Water) Patients Suffering from Congestive Heart FAILURE

S. K. is the only subject who showed an enhanced antidiuretic effect.

ADS is indeed not derived from the neurohypophysial antidiuretic hormone.

\section{Peak rate of diuresis}

While the peak rate of diuresis attained in the patients with cirrhosis was not significantly different statistically from that observed in the control subjects, the peak rate in the cardiac patients

TABLE II

Effect of Pitressin on serum electrolytes

\begin{tabular}{|c|c|c|c|c|c|c|c|c|c|c|c|c|}
\hline & \multicolumn{3}{|c|}{ Initial } & \multicolumn{3}{|c|}{ Diuresis } & \multicolumn{3}{|c|}{ Antidiuresis } & \multicolumn{3}{|c|}{ Final } \\
\hline & $\underset{m E q . / L}{\mathrm{Na}}$ & $\underset{m E q . / L}{\mathrm{Cl}}$ & $\underset{m E q . / L .}{\mathbf{K}}$ & $\underset{m E q . / L}{\mathrm{Na}}$ & $\underset{m E q . / L}{\mathrm{Cl}}$ & $\underset{m E q . / L}{\mathbf{K}}$ & $\underset{m E q . / L}{\mathrm{Na}}$ & $\underset{m E q . / L}{\mathrm{Cl}}$ & $\underset{m E q . / L}{\mathbf{K}}$ & $\underset{m E q . / L}{\mathrm{Na}}$ & $\underset{m E q . / L}{\mathrm{Cl}}$ & $\underset{m E q . / L}{\mathbf{K}}$ \\
\hline $\begin{array}{l}\text { Cardiacs: } \\
\text { S. K. } \\
\text { L. R. } \\
\text { H. D. } \\
\text { E. S. } \\
\text { G. M. } \\
\text { F. C. } \\
\quad \overline{\mathbf{x}} \\
\text { Liver Disease: } \\
\overline{\overline{\mathbf{x}}} \\
\text { Controls: } \\
\overline{\overline{\mathbf{x}}}\end{array}$ & $\begin{array}{l}121.9 \\
130.0 \\
131.5 \\
137.7 \\
136.2 \\
136.4 \\
132.3 \\
: 138.0 \\
137.4\end{array}$ & $\begin{array}{r}90.7 \\
98.7 \\
92.8 \\
96.0 \\
95.2 \\
97.3 \\
95.1 \\
104.0 \\
\\
103.7\end{array}$ & $\begin{array}{l}5.6 \\
4.8 \\
4.0 \\
3.9 \\
3.6 \\
4.3 \\
4.4 \\
\\
3.9 \\
\\
4.6\end{array}$ & $\begin{array}{l}120.2 \\
130.3 \\
128.6 \\
131.4 \\
131.1 \\
137.8\end{array}$ & $\begin{array}{l}90.0 \\
98.8 \\
91.0 \\
96.9 \\
91.2 \\
97.4\end{array}$ & $\begin{array}{l}5.1 \\
3.8 \\
3.8 \\
3.5 \\
3.6 \\
4.1\end{array}$ & $\begin{array}{l}121.6 \\
125.8 \\
129.1 \\
137.7 \\
125.9 \\
-\end{array}$ & $\begin{array}{l}90.4 \\
97.2 \\
92.1 \\
96.3 \\
91.2 \\
-\end{array}$ & $\begin{array}{l}5.4 \\
4.0 \\
3.6 \\
3.7 \\
3.5 \\
-\end{array}$ & $\begin{array}{c}121.5 \\
\overline{129.1} \\
135.0 \\
128.3 \\
-\end{array}$ & $\begin{array}{c}90.2 \\
\overline{93.4} \\
96.1 \\
90.2 \\
-\end{array}$ & $\begin{array}{l}5.3 \\
3.2 \\
3.4 \\
3.4 \\
-\end{array}$ \\
\hline
\end{tabular}


TABLE III

Urinary electrolyte excretion during hydration and Pitressin antidiuresis

\begin{tabular}{|c|c|c|c|c|c|c|c|c|c|c|c|c|c|c|}
\hline \multirow[b]{2}{*}{ Patients } & \multicolumn{5}{|c|}{ Hydration (H) } & \multicolumn{5}{|c|}{ Antidiuresis (A) } & \multicolumn{4}{|c|}{ (H) Minus (A) } \\
\hline & $\begin{array}{l}\text { Time } \\
\min .\end{array}$ & $\begin{array}{l}\text { Urine } \\
\text { flow } \\
\text { cc./ } \\
\text { min. }\end{array}$ & $\underset{\substack{\operatorname{mel} \\
\min . /}}{\mathrm{Cl}}$ & $\begin{array}{c}\mathrm{Na} \\
\operatorname{mEq.} \\
\min .\end{array}$ & 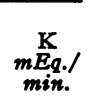 & $\begin{array}{l}\text { Time } \\
\text { min. }\end{array}$ & $\begin{array}{l}\text { Urine } \\
\text { flow } \\
c c . / \\
\text { min. }\end{array}$ & $\underset{\substack{\min \\
\min . /}}{\mathrm{Cl}}$ & $\underset{\text { mEq./ }}{\mathrm{Na}}$ & 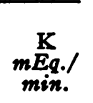 & $\begin{array}{l}\text { Urine } \\
\text { flow } \\
c c . / \\
\text { min. }\end{array}$ & $\underset{\substack{\min \\
\mathrm{Eq} . /}}{\mathrm{Cl}}$ & $\underset{\substack{\mathrm{Na} \\
\text { min. }}}{\mathrm{Na}}$ & $\underset{\substack{\min . \\
\mathrm{Eq} . /}}{\mathrm{K}}$ \\
\hline $\begin{array}{l}\text { Cardiacs: } \\
\text { S. K. } \\
\text { L. R. } \\
\text { H. D. } \\
\text { E. S. } \\
\text { G. M. } \\
\text { F. C. } \\
\quad \text { t } \\
\text { p }\end{array}$ & $\begin{array}{r}112 \\
68 \\
58 \\
63 \\
57 \\
57\end{array}$ & $\begin{array}{l}4.3 \\
6.8 \\
7.0 \\
6.4 \\
4.4 \\
9.9\end{array}$ & $\begin{array}{l}.017 \\
.015 \\
.012 \\
.012 \\
.012 \\
.019\end{array}$ & $\begin{array}{l}.003 \\
.003 \\
.011 \\
.013 \\
.013 \\
.007\end{array}$ & $\begin{array}{l}.063 \\
.022 \\
.045 \\
.023 \\
.017 \\
.079\end{array}$ & $\begin{array}{c}112^{*} \\
68^{*} \\
58 \\
63 \\
57 \\
57\end{array}$ & $\begin{array}{l}3.3 \\
4.3 \\
4.1 \\
3.3 \\
2.7 \\
5.2\end{array}$ & $\begin{array}{l}.014 \\
.023 \\
.015 \\
.009 \\
.010 \\
.016\end{array}$ & $\begin{array}{l}.004 \\
.003 \\
.009 \\
.007 \\
.009 \\
.007\end{array}$ & $\begin{array}{l}.044 \\
.018 \\
.052 \\
.024 \\
.017 \\
.064\end{array}$ & $\begin{array}{c}+1.0 \\
+2.5 \\
+2.9 \\
+3.1 \\
+1.7 \\
+4.7 \\
6.5 \\
.0013\end{array}$ & $\begin{array}{c}+.003 \\
-.008 \\
-.003 \\
+.003 \\
+.002 \\
+.003 \\
.94 \\
.41\end{array}$ & $\begin{array}{c}-.001 \\
.000 \\
+.002 \\
+.006 \\
+.004 \\
.000 \\
1.6 \\
.17\end{array}$ & $\begin{array}{r}-.019 \\
+.004 \\
-.007 \\
-.001 \\
.000 \\
+.015 \\
1.2 \\
.29\end{array}$ \\
\hline $\begin{array}{c}\text { Liver Disease: } \\
\mathbf{t} \\
\mathbf{p}\end{array}$ & & & & & & & & & & & $\begin{array}{l}4.8 \\
.0085\end{array}$ & $\begin{array}{l}.73 \\
.52\end{array}$ & $\begin{array}{c}1.9 \\
.13\end{array}$ & $\begin{array}{l}.15 \\
.93\end{array}$ \\
\hline $\begin{array}{c}\text { Controls: } \\
\mathbf{t} \\
\mathrm{p}\end{array}$ & & & & & & & & & & & $\begin{array}{l}9.7 \\
.0001\end{array}$ & $\begin{array}{l}.40 \\
.70\end{array}$ & $\begin{array}{l}.90 \\
.40\end{array}$ & $\begin{array}{c}1.6 \\
.16\end{array}$ \\
\hline
\end{tabular}

* Urine flow did not return to pre-Pitressin level during experimental period.

"Pre-Pitressin control period" $(\mathrm{H})$ is that portion of the intravenous hydration period which just precedes the Pitressin injection, and which is equal in time to the "antidiuresis period" for a given patient.

$\begin{aligned} & t=\frac{\bar{d}}{S_{\bar{d}}}, \text { where } \bar{d}=\text { difference between the means and } S_{\bar{d}}=S_{\bar{x}} \text { for }(H) \text { minus }(A) . \\ & p=\text { probability if } p=1.0, \text { then the observed difference is entirely a chance occurrence. } \\ & \text { if } p=0.0, \text { then there is no element of chance. }\end{aligned}$

was significantly lower than in the other two groups. Since the time required for the attainment of peak diuresis was normal and Pitressin was handled normally by the cardiac patients (with one exception), it is unlikely that abnormalities of $\mathrm{ADH}$ metabolism were responsible for the diminished peak diuresis.

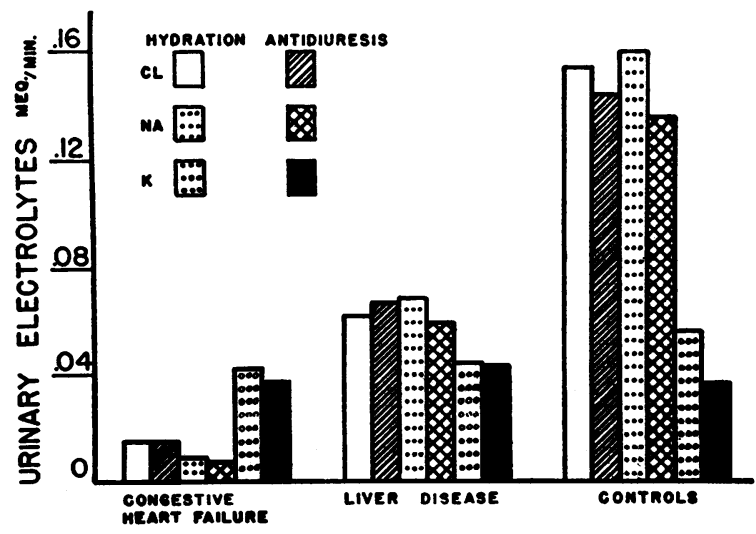

Fig. 4. The Effect of Intravenous Pitressin (0.57 MU Per Kg.) on the Average Urinary Excretion of Electrolytes in Congestive Heart Failure, Liver Disease and Control Subjects

Statistical analysis showed no significant difference among the three groups of patients with respect to the effect of Pitressin on the urinary electrolytes.
Among the differences noted in the cardiac patients from the other two groups were the diminished urinary excretion of sodium and a tendency for the endogenous creatinine clearances to be lower. Since the renal tubular reabsorption of sodium may be associated with that of water, increased reabsorption of the sodium ion might explain a smaller excretion of water. All else being equal, the level of peak diuresis is a function of the glomerular filtration rate, decreases in which would tend to diminish the level of peak diuresis attained (33).

\section{Pitressin Antidiuresis}

\section{Excretion of water}

As mentioned previously, Sinclair-Smith and co-workers (20) observed prolonged antidiuresis. in three patients with congestive heart failure. In the present experiments, only one of the cardiacs. (S. K.) demonstrated such prolongation. The data available do not definitely explain this unique behavior. Of the patients with congestive heart failure to whom Pitressin was administered, S. K. had the lowest endogenous creatinine clearance (42 cc. per min.), the lowest concentrations of sodium (121.9 mEq. per L.) and chloride ( 90.7 
mEq. per L.) and the highest concentration of potassium ( $5.6 \mathrm{mEq}$. per L.) in the serum. The possibility exists that these alterations in renal hemodynamics and serum electrolytes might be responsible for the prolonged antidiuretic response to Pitressin.

The normal responses of the older cardiac patients and of the patients with hepatic disease to Pitressin tend to exclude a decreased rate of inactivation (in physiological dosage) and also tend to eliminate the possibility of increased renal tubular sensitivity to the exogenous hormone. As we have discussed previously (14), to the extent that the inactivating mechanisms for exogenous Pitressin and endogenous $\mathrm{ADH}$ are similar, these results exclude a decreased rate of inactivation of $\mathrm{ADH}$ (in physiological amounts) in these disease states.

\section{Serum electrolytes}

While Pitressin (in the dosage used) tended to lower the serum sodium in the hepatic patients, it had no consistent effect on the concentrations of sodium, chloride, or potassium in the serum of patients with congestive heart failure. To the extent that the physiological effects of Pitressin and $\mathrm{ADH}$ are similar, one cannot ascribe the hyponatremia, that has been observed in some patients with congestive heart failure, to $\mathrm{ADH}$ circulating in normal amounts.

\section{Urinary electrolytes}

The urinary excretion of sodium and chloride was decreased in the patients with congestive heart failure. Part of this diminished excretion might be ascribed to their low intake of salt. Pitressin had no statistically significant effect on the urinary excretion of sodium, chloride, or potassium, and this parallels our previous findings in control subjects and in those with hepatic cirrhosis.

\section{Relationship to These Studies to the Question of Possible Over-production of $A D H$ in $\mathrm{He}$ - patic and Cardiac Disease}

We have referred to the reported increases of ADS in the urine of patients with congestive heart failure and in the serum and urine of those with hepatic cirrhosis. Our experiments were designed to determine whether such increases might result, in part, from a decreased rate of inactivation of
$\mathrm{ADH}$, and this seems to be excluded. Overproduction of $\mathrm{ADH}$ might then explain these increases of $\mathrm{ADS}$, if $\mathrm{ADS}$ is derived from $\mathrm{ADH}$. Since it has not been proved that ADS is indeed derived from $\mathrm{ADH}$ (34), overproduction of $\mathrm{ADH}$ in these disease states cannot be postulated with any degree of certainty at this time. Finally, as mentioned earlier in this discussion, the normal time for attainment of peak diuresis observed in both groups of patients might possibly be used to exclude hypersecretion of the neurohypophysial antidiuretic hormone in our patients with congestive heart failure as well as those with hepatic cirrhosis. Since the present series is relatively small, further study may reveal patients with more definite evidence of continued hypersecretion of $\mathrm{ADH}$.

\section{SUMMARY AND CONCLUSIONS}

1. Water diuresis following intravenous hydration with 5 per cent glucose in water at $10 \mathrm{cc}$. per min. was studied in ten patients suffering from congestive heart failure. The time required for peak diuresis to be reached was $99.1 \pm 32.1 \mathrm{~min}$ utes, which did not differ significantly from the control. However, the average level of peak diuresis, $6.7 \pm 3.3 \mathrm{cc}$. per min., differed significantly from that observed in control subjects, $12.0 \pm 2.6$ cc. per min., and in hepatic patients, $11.0 \pm 2.9 \mathrm{cc}$. per min.

2. Pitressin antidiuresis was studied in six of the cardiac patients. In four of these, the per cent inhibition of diuresis and the duration of Pitressin effect did not differ significantly from the control, but in one of the cardiacs there was a significantly enhanced Pitressin antidiuresis.

3. Pitressin, in the dosage used, did not affect the concentrations of serum sodium, chloride or potassium in the patients with congestive heart failure, but tended to lower the serum sodium of the hepatic patients.

4. To the extent that the "inactivating" mechanisms for Pitressin and the antidiuretic hormone $(\mathrm{ADH})$ are similar, our demonstration of normal rates of inactivation of Pitressin (in physiological dosage) in patients with hepatic cirrhosis or congestive heart failure tends to exclude a decreased rate of inactivation of $\mathrm{ADH}$ (in physiological amounts) in these diseases. 
5. If the reported increases of antidiuretic substance (ADS) in the blood and urine of such patients represent increased amounts of endogenous $\mathrm{ADH}$, then the exclusion of a decreased rate of inactivation of $\mathrm{ADH}$ would tend to favor increased production as an explanation for the findings. However, evidence available at present does not definitely establish the conclusion that such continued overproduction of $\mathrm{ADH}$ exists.

\section{ACKNOWLEDGMENTS}

The authors wish to thank Dr. Herbert Mark for his assistance in some of these studies.

\section{REFERENCES}

1. Eisenmenger, W. J., Blondheim, S. H., Bongiovanni, A. M., and Kunkel, H. G., Electrolyte studies on patients with cirrhosis of the liver. J. Clin. Invest., 1950, 29, 1491.

2. Eisenmenger, W. J., Rôle of sodium in the formation and control of ascites in patients with cirrhosis. Ann. Int. Med., 1952, 37, 261.

3. Peters, J. P.; The problem of cardiac edema. Am. J. Med., 1952, 12, 66.

4. Ralli, E. P., Leslie, S. H., Stueck, G. H., Jr., and Laken, B., Studies of the serum and urine constituents in patients with cirrhosis of the liver during water tolerance tests. Am. J. Med., 1951, 11, 157.

5. Peters, J. P., Sodium, water and edema. J. Mt. Sinai Hosp., 1951, 17, 159.

6. Gilbert, A., and Lereboullet, P., Des urines retardées (opsiurie) dans les cirrhoses. Compt. rend. Soc. de biol., 1901, iii, 229.

7. Adlersberg, D., and Fox, C. L., Jr., Changes of the water tolerance test in hepatic disease. Ann. Int. Med., 1943, 19, 642.

8. Fremont-Smith, F., The mechanism of edema formation. N. England J. Med., 1932, 206, 1286.

9. Lloyd, C. W., and Lobotsky, J., Serum antidiuretic substances and urinary corticosteroid in the human. J. Clin. Endocrinol., 1950, 10, 318.

10. Hall, C. A., Frame, B., and Drill, V. A., Renal excretion of water and antidiuretic substances in patients with hepatic cirrhosis and rats with dietary liver injury. Endocrinology, 1949, 44, 76.

11. Ralli, E. P., Robson, J. S., Clarke, D., and Hoagland, C. L., Factors influencing ascites in patients with cirrhosis of liver. J. Clin. Invest., 1945, 24, 316.

12. Van Dyke, H. B., Ames, R. G., and Plough, I. C., The excretion of antidiuretic hormone in the urine of patients with cirrhosis of the liver. Trans. A. Am. Physicians, 1950, 63, 35.

13. Bercu, B.' A., Rokaw, S. N., and Massie, E., Antidiuretic action of the urine of patients in cardiac failure. Circulation, 1950, 2, 409.

14. White, A. G., Rubin, G., and Leiter, L., Studies in edema. III. The effect of pitressin on the renal excretion of water and electrolytes in patients with and without liver disease. J. Clin. Invest., 1951, 30, 1287.

15. Nelson, W. P., III, and Welt, L. G., The effects of pitressin on the metabolism and excretion of water and electrolytes in normal subjects and patients. with cirrhosis and ascites. J. Clin. Invest., 1952, 31, 392.

16. Bernstein, S. H., Weston, R. E., Ross, G., Grossman, J., Hanenson, I. B., and Leiter, L., Studies on intravenous water diuresis and nicotine and pitressin antidiuresis in normal subjects and patients with liver disease. J. Clin. Invest., 1953, 32, 422.

17. Lewis, J. M., Buie, R. M., Sevier, S. M., and Harrison, $T$. R., The effect of posture and of congestion of the head on sodium excretion in normal subjects. Circulation, 1950, 2, 822.

18. Leaf, A., and Mamby, A. R., An antidiuretic mechanism not regulated by extracellular fluid tonicity. J. Clin. Invest., 1952, 31, 60.

19. Strauss, M. B., Davis, R. K., Rosenbaum, J. D., and Rossmeisl, E. C., Production of increased renal sodium excretion by the hypotonic expansion of extracellular fluid volume in recumbent subjects. J. Clin. Invest., 1952, 31, 80.

20. Sinclair-Smith, B. C., Sisson, J., Kattus, A. A., Genecin, A., Monge, C., McKeever, W., and Newman, E. V., The effects of posterior pituitary extract and smoking on water, sodium and.chloride excretion in normal subjects and in patients with congestive cardiac failure. Bull. Johns Hopkins. Hosp., 1950, 87, 221.

21. Fox, C. L., Jr., Friedburg, C. K., and White, A. G., Electrolyte abnormalities in chronic congestive heart failure; effects of administration of potassium and sodium salts. J. Clin. Invest., 1949, 28, 781.

22. Miller, G. E., Water and electrolyte metabolism in congestive heart failure. Circulation, 1951, 4, 270.

23. Squires, R. D., Singer, R. B., Moffitt, G. R., Jr., and Elkinton, J. R., The distribution of body fluids in congestive heart failure. II. Abnormalities in serum. electrolyte concentration and in acid-base equilibrium. Circulation, 1951, 4, 697.

24. Weston, R. E., Hanenson, I. B., Borun, E. R., Grossman, J., and Wolfman, M., Production of water retention and acute hyponatremia without sodium loss by administration of pitressin tannate to patients in congestive heart failure. J. Clin. Invest., 1952, 31, 672.

25. Stead, E. A., Jr., Edema and dyspnea of heart failure. Bull. New York Acad. Med., 1952, 28, 159.

26. Peters, J. H., The determination of creatinine and creatine in blood and urine with the photoelectric colorimeter. J. Biol. Chem., 1942, 146, 179.

27. Butler, A. M., and Tuthill, E., An application of the uranyl zinc acetate method for determination of sodium in biological material. J. Biol. Chem., 1931, 93, 171. 
28. Van Slyke, D. D., and Hiller, A., Application of Sendroy's iodometric chloride titration to proteincontaining fluids. J. Biol. Chem., 1947, 167, 107.

29. Benedict, S. R., The detection and estimation of glucose in urine. J. A. M. A., 1911, 57, 1193.

30. Mather, K., Statistical Analysis in Biology, 2nd ed., Interscience Pub., N. Y., 1947.

31. Lemon, H. M., Chason, W. H., and Looney, J. M., Abnormal glycine metabolism in rheumatoid arthritis. J. Clin. Invest., 1952, 31, 993.
32. Burn, G. P., and Grewal, R. S., The antidiuretic response to and excretion of pituitary (posterior lobe) extract in man, with reference to the action of nicotine. Brit. J. Pharmacol., 1951, 6, 471.

33. Smith, H. W., The Kidney: Structure and Function in Health and Disease, Oxford Univ. Press, N. Y., 1951.

34. van Dyke, H. B., The regulation of water excretion by the neurohypophyses. Bull. New York Acad. Med., 1953, 29, 24. 